\title{
Corporate Disclosures, Information Asymmetry And Stock-Market Liquidity In France
}

Aymen Ajina, HEC Management School - University of Liège, \& ISG-University of Sousse, Tunisia Danielle Sougne, University of Liège, Belgium

Faten Lakhal, University of Sousse, Tunisia

\begin{abstract}
This paper aims at studying the effect of corporate disclosures on information asymmetry and stock-market liquidity in France. Specifically, the purpose of this paper is to highlight the importance of information included in the annual reports on investor's behavior. This is proxied by the information asymmetry component of the bid-ask spread and stock market liquidity. Our sample includes 196 French listed firms over a period ranging from 2004 to 2007. The results show that the extent of corporate disclosures in annual reports positively influences the liquidity of the French market and negatively affects the adverse selection component of the bid-ask spread. This effect is further confirmed by the commitment to IFRS by French-listed firms since 2005. Results on sub-scores show that non-financial and financial information are important in trading decisions while strategic information may be attractive only for long-term positions.
\end{abstract}

Keywords: Market Liquidity; Information Asymmetry; Adverse Selection Component; Corporate Disclosure

\section{INTRODUCTION}

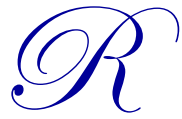

ich informational environment is likely to enhance stock market liquidity and to reduce the firm's cost of capital (Botosan and Plumlee 2002; Hail 2002). This theoretical finding shows a practical interest to managers to regularly disclose financial information. The aim is to limit information asymmetry between well-informed and uninformed investors, and to increase the quantity of asset transactions. In this paper, we examine the relationship between corporate disclosure, information asymmetry and asset liquidity in the French market.

Having studied this relationship, researchers rely on two main hypotheses. The first one is the trading hypothesis, according to which, the transaction volume induced by more transparency enhances stock liquidity. Indeed, rich informational environment attracts investors who will be encouraged to make transactions. This results in lower transaction costs, and hence, better market liquidity (Healy and Palepu, 2001). The second hypothesis is the adverse selection, assuming the existence of an informational asymmetry between informed and uniformed investors. Signaling through information's mechanisms leads to decrease the adverse selection component of the spread, and hence, to increase market liquidity (Glosten and Milgrom 1985). The study of the relationship between information disclosure and liquidity requires the existence of two types of costs (adverse selection costs and transaction costs). These costs may be mitigated by the mechanisms of corporate information.

Few researches have examined the effect of financial disclosure on asset liquidity ${ }^{1}$. Lakhal (2008) is one of the few researchers who have studied this issue within the French context. These studies focused on the instant

\footnotetext{
${ }^{1}$ Acker and al., 2002 in England; Botosan and Forst, 2000 in the U.S.; Heflin and al., 2005 in the U.S; Leuz and Verrecchia, 2000 in Germany, Espinosa and al., 2008 in Spain. 
effect of disclosure on the market (the « association based-theory » approach). This research is innovative, in that it studies an order-driven market, the effect of the extent of a disclosure policy on liquidity and information asymmetry, and is in line with the "Efficiency-based disclosure" approach. This approach stresses on the effectiveness of information disclosure by each company and considers the information mechanisms useful unless they reduce information asymmetry between market participants (Verrecchia, 2001).

The purpose of this paper is to shed the light on the influence of corporate information environment on stock market liquidity. It provides a new empirical evidence on the French market. Our study period was characterized by the compliance with IFRS. These standards are intended to harmonize financial information companies to preserve confidence in financial markets and to improve the quality of information disclosed. Therefore, the compliance with IFRS standards could result in an improved liquidity.

The findings show that corporate disclosure has a positive impact on the French market liquidity. The information disclosure increases the company's visibility and shrinks information asymmetry between wellinformed and uninformed investors, which should increase market liquidity. The results also show that information disclosure reduces information asymmetry through a low level of the adverse selection component of the spread. These effects are most pronounced with the IFRS adoption starting from 2005 in France.

This article is organized as follows: The first section presents the theoretical framework for the information disclosure, asset liquidity and information asymmetry. The second section presents the sample and the methodology, followed by results and discussions. The last section concludes the paper.

\section{LITERATURE REVIEW AND HYPOTHESES DEVELOPMENT}

\subsection{Information Disclosure And Market Liquidity}

The theoretical literature suggests that disclosure improves liquidity by reducing the information asymmetry on the one hand, and increased transaction volumes on the other one. According to the theoretical contribution of Verrecchia (2001), corporate disclosure is intended at reducing information asymmetry. Indeed, the distribution of information between economic agents leads to an increase in the degree of adverse selection, and exacerbates the bid ask spread. Petersen and Plenborg (2006) show that corporate information reduces information asymmetry, by increasing investors' confidence and hence, the number of transactions. Cohen (2006) shows that a rich informational environment is likely to reduce the bid-ask spread and increase market liquidity. Botosan and Forst (2000) study the relationship between disclosure and stock market liquidity on a sample of firms listed on the NYSE. The authors find a negative but not significant relationship between the bid ask spread and corporate disclosure.

According to the trading theoretical hypothesis, investors incur costs in each of their transactions. These costs are divided between explicit and implicit components (Biais, Hillion and Foucault 1997). Explicit costs include the fees and taxes incurred when switching from an order, decreasing the profitability of all operations. These costs are reduced by a good level of transparency. Amihud and Mendelson (1980) and Glosten and Milgrom (1985) emphasize the close relationship between financial transparency and transaction costs. According to Diamond and Verrecchia (1991), if the company discloses more information, this will reduce the imbalance of orders between informed and uninformed investors and promotes the reduction of inside information revealed by the large transactions. This is likely to increase investors' confidence and hence the volume of transactions in this context. Bailey et al. (2003) and Francis et al. (2006) show that the trading volume, incurred by high level of transparency, improves liquidity.

As far as the trading hypothesis is concerned, Heflin et al. (2005) find evidence that a high level of voluntary disclosure mitigates information asymmetry problems leading to a decrease in the transaction cost. In a similar vein, Healy et al. (1999) document a negative relationship between the levels of a voluntary disclosure and bid-ask spread. They conclude that a greater disclosure reduces information asymmetry among market participants, thereby reducing the adverse selection problem and increasing market liquidity. Brown and Hillegeist (2007) also 
show that firms followed by analysts are likely to have a rich-informational environment by reducing the incentive to acquire private information, the cost of collecting and processing information and therefore the transactions' cost.

In the Spanish context, Espinosa et al. (2008) examine the relationship between a corporate disclosure and stock market liquidity of securities between 1994 and 2000. The authors show a positive relationship between liquidity and financial disclosure. Lakhal (2008) examines the impact of voluntary earnings announcements on the liquidity of the French market. The author proves that quarterly announcements improve market liquidity by reducing bid ask spreads and increasing trading volumes. In Germany, Grüning (2010) shows that corporate disclosures improve liquidity because they are likely to influence investors' expectations and the adjustments of their portfolios.

In the light of the preceding discussion, we hypothesize the following:

H1: There is a positive relationship between information disclosure and stock market liquidity.

\subsection{Information Disclosure And The Adverse Selection Component}

The market microstructure theory is well-developed in the price-driven markets. Accordingly, Huang and Stoll (1997) propose a decomposition of the bid ask spread. However, the bid ask spread is not limited to pricedriven markets. Cohen et al. (1981) have established the existence of spreads in order-driven markets. Based on a sample of 6,084,811 observations of the Hong Kong Stock Exchange, Brockman and Chung (1999) examine the components of the spreads in an order-driven market. They approximate a 33\% median for the adverse selection component, $45 \%$ for the order processing and persistence of order of about $22 \%$ of the spread.

The predictions of the theoretical adverse selection hypothesis confirm the existence of information asymmetries in the market. According to Copeland and Galai (1983), the costs of adverse selection result from the existence of informed agents whose earnings are at the expense of uninformed agents. These costs are likely to expand the spread to cover losses related to the presence of informed investors. Therefore, in the presence of information asymmetry, spread widens (Handa, Schwartz and Tiwari, 1998). The information's mechanisms aim at reducing the adverse selection component of the spread in the presence of asymmetric information. In the German market, Leuz and Verrecchia (2000) examine 102 German firms listed on the DAX 100. They report that firms following either IAS or US GAAP exhibit lower spreads and higher turnover than firms following German GAAP firms, but are unable to document significant differences across IAS and US GAAP firms.

Charoenwong et al. (2011) are among the few to study the effect of governance quality and information transparency on the adverse selection component of the spread. They find that corporate information in Singapore is significantly and negatively related to the information asymmetry component. They conclude that investors are interested in a better transparency as it allows them to reduce the cost of their investment by reducing the information asymmetry component resulting in a lower spread.

The study of French companies allows us to study the effect of information disclosure on the adverse selection component for an order driven- market by highlighting the role of information mechanisms in reducing adverse selection costs. Unlike the study of Leuz and Verrecchia (2001), which focuses on companies that voluntarily comply with IFRS, we study this effect in a context where the application of IFRS requires further improving of the quality of information disclosed. The above discussion leads to the following hypothesis:

H2: There is a negative relationship between corporate disclosure and the adverse selection component.

\section{SAMPLE AND METHODOLOGY}

\subsection{Data Collection}

Our sample includes all industrial and commercial companies listed on the SBF 250 index over a period of 4 years (2004-2007). Financial companies were excluded because they are subject to specific disclosure 
requirements. Financial data related to stock prices, trading volumes and bid and ask prices were retrieved from Datastream database. Information related to corporate disclosures were extracted from the selected companies' annual reports. These reports were located at the Euronext website and firms' web sites. The Financial data were extracted from the Thomson One Banker database.

Table 1 shows the distribution of sample firms across industries. Commercial companies (consumer goods) represent $29 \%$ of the whole sample. The percentage of service sector (General Retailers, consumer services, Media, telecommunications and utilities) is the most important of about $34.3 \%$ of the total sample while the proportion of high-tech companies is $14.30 \%$.

Table 1. Sample Selection Procedure

\begin{tabular}{lccc}
\hline \multicolumn{1}{c}{ Sector } & $\begin{array}{c}\mathbf{I C B}^{\mathbf{2}} \text { Industry code (Thomson } \\
\text { Financial Reuters) }\end{array}$ & Number of companies & \% \\
\hline Basic Materials & $\mathbf{1 0 0 0}$ & 17 & 8.6 \\
Industrials & $\mathbf{2 0 0 0}$ & 27 & 13.8 \\
Consumer Goods & $\mathbf{3 0 0 0}$ & 57 & 29 \\
Health care & $\mathbf{4 0 0 0}$ & 26 & 13.3 \\
Consumer Service & $\mathbf{5 0 0 0}$ & 27 & 13.8 \\
Telecommunication & $\mathbf{6 0 0 0}$ & 6 & 3.1 \\
Utilities & $\mathbf{7 0 0 0}$ & 8 & 4.1 \\
Technology & $\mathbf{9 0 0 0}$ & 28 & 14.3 \\
\hline Total & & $\mathbf{1 9 6}$ & $\mathbf{1 0 0 \%}$ \\
\hline
\end{tabular}

\subsection{Definition And Variables' Measures}

\subsubsection{Stock Market Liquidity}

Liquid markets enable the immediate execution of standard orders, exhibit prices that are resilient to large orders, and have enough participants trading and sufficient volume to ensure low transaction costs (Newbery et al. 2003). Kyle (1985) quite aptly coined the phrase "market liquidity" a slippery and elusive concept, partly because it covers a number of transactional properties of markets. According to this author, "these include 'tightness' (the cost of turning around a position over a short period of time), 'depth' (the size of an order flow innovation required to change prices a given amount), and 'resiliency' (the speed with which prices recover from a random, uninformative shock)." Black (1971) describes intuitively a liquid market in the following manner: "The market for a stock is liquid if the following conditions hold: (1) there are always bid and asked prices for the investor who wants to buy or sell small amounts of stock immediately. (2) The difference between the bid and asked prices (the spread) is always small. (3) An investor who is buying or selling a large amount of stock, in the absence of special information, can expect to do so over a long period of time at a price not very different, on average, from the current market price. (4) An investor can buy or sell a large block of stock immediately, but at a premium or discount that depends on the size of the block.

This research is based on the bid-ask spread as a measure for liquidity. The bid-ask spread includes the issue of the adverse selection while investing in information asymmetric companies. In case of information asymmetry, the bid-ask spread exacerbates and liquidity decreases (Ascioglu and al. 2007).

$$
\text { Quoted spreads }=\frac{A s k_{t}-\text { Bid }_{t}}{\frac{A s k_{t}+B i d_{t}}{2}}
$$

\footnotetext{
${ }^{2}$ ICB (Industry Classification Benchmark): is a company classification system developed by Dow Jones and FTSE. It is used to segregate markets into sectors within the macroeconomy. The ICB uses a system of 10 industries, partitioned into 19 supersectors, which are further divided into 41 sectors, which then contain 114 subsectors.
} 
With:

$\mathrm{Ask}_{\mathrm{t}}=$ Best bid price in $\mathrm{t}$;

$\mathrm{Bid}_{\mathrm{t}}=$ Best asked price in $\mathrm{t}$

\subsubsection{The Information Asymmetry Component}

In order-driven markets, like the Paris stock-exchange, the spread is given by the order book, and equals to the difference between the best price associated with a selling limit order (ask price) and the best price associated with a buying limit order (bid price). Market microstructure literature shows that the spread comprises three components: order processing costs, adverse selection costs, and inventory holding costs. The adverse selection component of the spread balances the liquidity suppliers for transacting with better informed traders, and increases with the degree of information asymmetry. Bagehot (1971) argue that some traders possess superior information as compared to liquidity suppliers. Consequently, liquidity suppliers always lose when trading with informed traders. They are able to remain solvent only by offsetting these losses with trading gains from uninformed traders (Copeland and Galai 1983; Glosten and Milgrom 1985).

Empirically, several analyses present methods to estimate the spread components. Huang and Stoll (1997) propose to consider two broad classes of spread decomposition models. The first class decomposes the spread using serial covariance properties of quotes and transaction prices. Models were developed by Stoll (1989) and George, Kaul, and Nimalendran (1991), based on Roll (1984), and Choi, Salandro, and Shastri (1988) estimations of the spread. The second class uses a trade direction indicator regression to decompose the spread. These trade indicator models are mainly driven by whether incoming orders are purchases or sales and the response of the price to this order arrival. Models are those of Glosten and Harris (1988), Lin, Sanger and Booth (1995), Madhavan, Richardson, and Roomans (1996) and Huang and Stoll (1997).

Clarke and Shastri (2001), Van Ness, Van Ness et Warr (2001) and Winne and Majois (2004) view this model as one of the most appropriate to study the bid-ask spread components. Hence, this method appears to be the most appropriate for the Paris stock-exchange and also the most robust concerning components estimation. Lin, Sanger and Booth (1995) designed their model ${ }^{3}$ on the basis of Huang and Stoll (1994), Lin (1992) and Stoll's approach (1989).

\subsubsection{The Extent Of Corporate Disclosure: The Disclosure Index}

The extent of corporate disclosures is based on a disclosure index. A disclosure checklist was compiled on the basis of the existing literature by Botosan (1997) and Eng and Mak (2003).

The developed disclosure index is composed of a comprehensive checklist of 112 items and is computed for all the 196 sampled French firms during 2004 to 2007. The items were classified into three categories: (1) strategic information (the company's history, its organization structure, activity, main products and markets, current and future strategies and perspectives; 30 items), (2) the non-financial information (the number of employees and their salaries, the value added per employee and the productivity indicators; 46 items), and (3) the financial information (performance indicators other than those collected from financial statements, the financial ratios, forecasts and other useful financial information; 36 items).

We compute a disclosure index by assigning a point for each item when disclosed on the annual report. This dichotomous basis was used in prior studies by Cooke (1989). The total score is calculated as an unweighted sum of the scores of each item which assumes their equal importance.

\footnotetext{
${ }^{3}$ Further details to be found in Lin, Sanger et Booth (1995).
} 


\subsubsection{Control Variables}

Theoretical and empirical studies suggest numerous determinants of stock market liquidity. These factors rise from the empirical models of the bid-ask spread components. According to the market microstructure literature, a bid-ask spread includes three components. Demsetz (1968) and Tinic (1972) identify the order-processing costs incurred by the providers of liquidity and proxied by trading volumes. Stoll (1978) and Amihud and Mendelson (1980) highlight the inventory holding costs measured by trading volumes and volatility. Copeland and Galai (1983) and Glosten and Milgrom (1985) focus on the information asymmetry costs faced by liquidity suppliers trading with informed investors. Several measures of adverse selection costs have been used in literature. The bid-ask spread should increase with volatility, while it should decrease with the size of the firm and trading volume (Demsetz 1968; Amihud et Mendelson 1980; Brockman et Chung 2001). From the bid-ask spread components above-mentioned, the extant literature put forward the determinants of bid-ask spread, namely: trading volume, price volatility, share price, firm size, Listing in the U.S Market, and IFRS.

\subsubsection{Trading Volumes}

Lee et al. (1993) point out that the evolution of the spread can not be disconnected from changes in trading volumes. The relationship between the trading volumes and liquidity is ambiguous. Hand (1992), Admati and Pfeleider (1998) assert that there is a positive correlation between those two entities. This is explained by the fact that investors tend to concentrate their trading at the same time in order to benefit from a greater liquidity. Similarly, Gregoriou, Ioamnidis and Skerrat (2002) foresaw the same kind of relation. However, Lin Sanger and Booth (1995) maintain that the trading volumes imply an adverse selection problem as the informed investors prefer to negotiate important volumes in order to take advantage from their information. So the rise of the trading volumes brings about disequilibrium in the market and leads to extra costs that have to be recouped by the enlargement of the spread. This variable is measured by the annual average of the trading volumes. We expect the relationship between the spread and the trading volumes to be negative.

\subsubsection{Price Volatility}

Price volatility measures the information content and information asymmetry in the market. Indeed, any change in prices following a change in investors' expectations leads to an increase in the variance of returns. Ascioglu et al. (2007) show that volatility affects inventory holding costs and risk of stock management. It is positively associated with bid-ask spreads. Heflin and Shaw (2000), Espinosa et al. (2008) and Chae (2005) prove a negative relationship between liquidity and the volatility of prices. Volatility is measured by the annual average of the standard deviation of equity returns. We expect a positive relationship between bid ask spread and volatility.

\subsubsection{Share Price}

The microstructure of financial markets stipulates that the price explains a significant part of the liquidity of shares. While some authors have shown that share price is positively associated with levels of liquidity (Sarin, Shastri and Shastri 2000, Dennis and Weston 2001; Attig et al. 2006), others advocate a negative relationship between the price of shares and their liquidity (Heflin et al. 2005; Sharma 2005). This variable is measured by the average of the daily closing prices of each year. The relationship between share price and bid-ask spreads is expected to be negative.

\subsubsection{Firm Size}

It is considered as a proxy of information asymmetry and agency costs. Indeed, Chae (2005) suggests that small companies incur high level of information asymmetry. Moreover, equities firms with weak market capitalization are less liquid (Lafond, Lang and Skaife 2007; Heflin et al. 2005). Consequently, we anticipate a positive association between firm size and bid-ask spreads. Firm size is measured by the natural logarithm of yearend market capitalization. 


\subsubsection{US Listing}

US listing is considered as one of the essential characteristics that may influence the decision of publication (Ding et Stolowy 2003). Indeed, when a company is publicly listed on U.S. markets, it must comply with the requirements of these markets and publish its accounts under U.S.GAAP. Lakhal (2006) and Leuz and Verrecchia (2001) argue that trading on more than one market is among the reasons that may encourage leaders to become more inclined to inform the market. The application of these standards and subsequently the higher level of published information is perceived as a positive signal by the market, thereby increasing confidence among investors. This is likely to attract investors to invest in these companies, thus increasing the volume of transactions. We expect a positive association between listing on the U.S. market and liquidity.

\subsubsection{IFRS}

IFRS are intended to enable investors and analysts to better understand the economic reality of companies. The wealth, relevance and precision of the information produced under IFRS should lead companies to produce annual reports more informative. Maghraoui and Dumontier (2006) studied the relationship between the adoption of IFRS and the information asymmetry measured by the spread of a sample of German companies. The results show that the spreads are lower after the application of these standards. Gassen and Sellhorn (2006) reached the same results. Since 1 January 2005, IFRS are required for all EU listed companies (Directive 2004/109). We introduce a dummy variable taking the value of 1 for observations from years 2005-2007 and 0 for 2004 and we expect a positive effect of IFRS on market liquidity.

Table 2. Definition And Variable Measurement

\begin{tabular}{|c|c|c|c|c|}
\hline Variable & Definition & Measurements & Auteurs & Signe prévu \\
\hline \multicolumn{5}{|c|}{ Dependent variables: } \\
\hline QBASP & Quoted spread & $\begin{array}{l}\text { The annual average of the difference } \\
\text { between the daily bid price and ask } \\
\text { price. }\end{array}$ & $\begin{array}{l}\text { Heflin et al. (2005), Espinosa } \\
\text { et al. (2008) }\end{array}$ & \\
\hline SEAD & Adverse selection & $\begin{array}{l}\text { adverse selection component of the } \\
\text { spread (Lin, Sanger et Booth ,1995) }\end{array}$ & Heflin et al. (2005) & \\
\hline \multicolumn{5}{|c|}{ Independent variables } \\
\hline SCOR & disclosure index & $\begin{array}{l}\text { The total points from the } \\
\text { index published for each company }\end{array}$ & $\begin{array}{l}\text { Leuz and Verrecchia (2000), } \\
\text { Heflin et } a l . \text { (2005), Espinosa } \\
\text { et } a l .(2008)\end{array}$ & $(-)$ \\
\hline \multicolumn{5}{|c|}{ Control variables: } \\
\hline VOLM & Trading volume & $\begin{array}{l}\text { The annual average of daily trading } \\
\text { volume. }\end{array}$ & $\begin{array}{l}\text { Bartov et Bodnar (1996), Lin, } \\
\text { Sanger et Booth (1995) }\end{array}$ & $(-)$ \\
\hline VOLAT & Volatility & $\begin{array}{l}\text { The annual average of the standard } \\
\text { deviation of equity returns }\end{array}$ & $\begin{array}{l}\text { Barnea and Logue (1975), } \\
\text { Ascioglu et al. (2007), Chae } \\
(2005)\end{array}$ & $(+)$ \\
\hline PRICE & Price & $\begin{array}{l}\text { The average of the daily closing price, } \\
\text { of each year }\end{array}$ & $\begin{array}{l}\text { Heflin et al. (2005); Sharma } \\
(2005)\end{array}$ & $(+/-)$ \\
\hline SIZE & Firme size & $\begin{array}{l}\text { The natural logarithm of year end } \\
\text { market capitalization. }\end{array}$ & $\begin{array}{l}\text { Lafond, Lang and Skaife, } \\
\text { (2007), Chae (2005) } \\
\text { Lafond, Lang et Skaife, (2007), } \\
\text { Chae (2005) }\end{array}$ & $(-)$ \\
\hline USCOT & $\begin{array}{l}\text { Listing in the U.S } \\
\text { Market }\end{array}$ & $\begin{array}{l}\text { Dummy variable } 1 \text { if the company } \\
\text { listing in the U.S Market and } 0 \text { if not. }\end{array}$ & $\begin{array}{l}\text { Lakhal (2006), Leuz and } \\
\text { Verrecchia (2001) }\end{array}$ & $(-)$ \\
\hline IFRS & IFRS standards & $\begin{array}{l}\text { Dummy variable, } 1 \text { for observations } \\
\text { from years } 2005-2007 \text { and } 0 \text { for } 2004\end{array}$ & $\begin{array}{l}\text { Dumontier et Maghraoui } \\
\text { (2006), Gassen and Sellhorn } \\
\text { (2006) }\end{array}$ & $(-)$ \\
\hline
\end{tabular}

\subsection{Methodology}

The multiple regression methodology with panel data is used. Panel data analyses include two special dimensions: an individual dimension, as indicated by the $i$ index, standing for the company, and a $t$ index standing 
for the period dimension (Gujarati, 2004). The Hausman test is used to choose between fixed effect and random effect models. The results of the Hausman test, not reported here, show that the fixed effect model is preferable to the random effect.

We estimate the following models:

$$
\begin{aligned}
& \text { Liquidité }_{i t}=\alpha_{0}+\alpha_{t} \text { SCOR }_{i t}+\alpha_{2} \text { LnVOLM }_{i t}+\alpha_{3} \text { LnVOLAT }_{i t}+\alpha_{4} \operatorname{LnPRICE}_{i t}+\alpha_{5} \operatorname{SIZE}_{i t}+ \\
& \alpha_{6} U_{S C O T}+\alpha_{7} I_{i t}+\mu_{i}+\varepsilon_{i t} \\
& \text { Liquidité }_{i t}=\alpha_{0}+\alpha_{1} \text { STRAG }_{i t}+\alpha_{2} \text { NFINAN }_{i t}+\alpha_{3} \text { FINAN }_{i t}+\alpha_{4} \text { LnVOLM }_{i t}+ \\
& \alpha_{5} \operatorname{LnVOLAT}_{i t}+\alpha_{6} \operatorname{LnPRICE}_{i t}+\alpha_{7} \operatorname{SIZE}_{i t}+\alpha_{8} \mathrm{USCOT}_{i t}+\alpha_{9} I_{F R S_{i t}}+\mu_{i}+\varepsilon_{i t} \\
& \operatorname{LnSELAD}_{i t}=\alpha_{0}+\alpha_{1} \operatorname{SCOR}_{i t}+\alpha_{2} \text { LnVOLM }_{i t}+\alpha_{3} \operatorname{LnVOLAT}_{i t}+\alpha_{4} \operatorname{LnPRICE}_{i t}+\alpha_{5} \operatorname{SIZE}_{i t}+ \\
& \alpha_{6} U_{S C O T}+\alpha_{7} I F R S_{i t}+\mu_{i}+\varepsilon_{i t} \\
& \operatorname{LnSELAD}_{i t}=\alpha_{0}+\alpha_{1} \operatorname{STRAG}_{i t}+\alpha_{2} \text { NFINAN }_{i t}+\alpha_{3} \text { FINAN }_{i t}+\alpha_{4} \text { LnVOLM }_{i t}+ \\
& \alpha_{5} \operatorname{LnVOLAT}_{i t}+\alpha_{6} \text { LnPRICE }_{i t}+\alpha_{7} \operatorname{SIZE}_{i t}+\alpha_{8} U_{S C O T}+\alpha_{9} I F R S_{i t}+\mu_{i}+\varepsilon_{i t}
\end{aligned}
$$

\section{ANALYSIS AND DISCUSSION}

\subsection{Descriptive Statistics}

Table 2 provides descriptive statistics and presents sample characteristics. The disclosure score is on average equal to $55.47 \%$ (median, $58 \%$ ). This score ranges from a maximum percentage of $79.5 \%$ and a minimum value of $20.4 \%$ suggesting that companies' disclosure policies vary significantly among French firms.

We notice that the quoted spreads equals to $0.81 \%$ on average, whereas the Anglo-Saxon market's bid-ask spread is usually lower and amounts to $0.162 \%$ on the North-American market, as measured by Heflin et al. (2005) on the North-American market. According to Sarin, Shastri and Shastri (2000), the American spread level equals 0.012 on average. Therefore, we believe that the French financial market is less liquid than Anglo-Saxon markets.

Table 3. Descriptive Statistics

\begin{tabular}{lccccc}
\hline & Moyenne & Médiane & Ecart-type & Max & Min \\
\hline QBASP & 0.0081 & 0.0061 & 0.0118 & 0.2477 & 0.0002 \\
ADSE & 0.0015 & 0.0011 & 0.002 & 0.0037 & 0 \\
SCOR & 0.5547 & 0.584 & 0.1545 & 0.79584 & 0.204 \\
VOLM & 986.697 & 198.75 & 2453 & 19756 & 4.029 \\
VOLAT & 0.0754 & 0.066 & 0.0416 & 0.3936 & 0.0189 \\
PRICE & 48.991 & 34.817 & 70.455 & 735.6 & 0.8858 \\
SIZE & 6.8905 & 6.4973 & 1.7238 & 11.756 & 1.8357 \\
\hline & Nombre & Fréquence & & & \\
USCOT & 74 & 0.377 & & & \\
\end{tabular}

This table reports descriptive statistics for a sample of 196 French listed firms over 2004 and 2007. QBASP: is the averaged quoted spreads, EBASP: is the averaged effective spread. ADSE: adverse selection component of the spread. SCOR: The total points from the index published for each company. VOLM: is the logarithm of the averaged volume exchanged. VOLAT: is by the annual average of stock return standard deviation. PRICE: is the 
annual average of daily closing price. SIZE: is the size of the company measured by the natural logarithm of year end market capitalization. USCOT: dummy variable 1 if the company listing in the U.S Market and 0 if not.

A bivariate analysis has been carried out in order to assess any potential multicollinearity problem between any independent variable, which might cause estimated coefficient instability and increasing standard deviation. According to Gujarati (2004), such a problem might occur when the variable correlation exceeds 0.80 .

Results have shown that correlations between explanatory variables are quiet low. However, some explanatory variables appear significantly correlated. The size of the company is positively correlated (associated) to the disclosure index and the asset price on $1 \%$ threshold. Nevertheless, the coefficient correlation is quite low ( 0.163 and 0.340 respectively). There is a negative relationship between the bid-ask spread and the disclosure index. This preliminary result is consistent with our hypothesis. A second multicollinearity measure has therefore been used (the VIF: Variance Inflation Factor). The VIF values range from 1,21 to 3,48, far below 10 which is the critical value as defined by Neter, Wasserman and Kunter (1989).

Table 4. Correlation Matrix

\begin{tabular}{|c|c|c|c|c|c|c|c|c|c|c|c|c|}
\hline & QBASP & VOLM & VOLAT & PRICE & SIZE & SCOR & STRAT & NFINAN & FINAN & IFRS & USCOT & VIF \\
\hline QBASP & 1 & $-0,746^{* *}$ & $0,246^{* *}$ & $-0,185^{* *}$ & $-0,744^{* *}$ & $-0,218^{* *}$ & $-0,044$ & $-0,31 * *$ & $-0,141 * *$ & $0,158 * *$ & $-0,608 * *$ & \\
\hline VOLM & & 1 & $-0,063$ & $-0,103 * *$ & $0,6^{* *}$ & $0,202 * *$ & 0,03 & $0,247 * *$ & $0,165 * *$ & 0,015 & $0,541 * *$ & 2,745 \\
\hline VOLAT & & & 1 & $-0,255^{* *}$ & $-0,321 * *$ & $-0,135^{* *}$ & $-0,062$ & $-0,143^{* *}$ & $-0,028$ & $-0,031$ & $-0,17 * *$ & 1,215 \\
\hline PRICE & & & & 1 & $0,34 * *$ & 0,01 & $-0,039$ & $0,181 * *$ & $-0,035$ & $-0,196 * *$ & $0,131 * *$ & 2,482 \\
\hline SIZE & & & & & 1 & $0,156^{* *}$ & 0,079 & $0,262 * *$ & $0,174 * *$ & $-0,106^{* *}$ & $0,533 * *$ & 2,226 \\
\hline SCOR & & & & & & 1 & $0,154 * *$ & $0,283^{* *}$ & 0,053 & $-0,008$ & $0,125^{* *}$ & 2,521 \\
\hline STRAT & & & & & & & 1 & $-0,023$ & $-0,105 * *$ & $-0,0037$ & $-0,023$ & 1,453 \\
\hline NFINAN & & & & & & & & 1 & 0,026 & $-0,0036$ & 0,332 & 1,866 \\
\hline FINAN & & & & & & & & & 1 & $-0,0006$ & $0,095 * *$ & 2,136 \\
\hline IFRS & & & & & & & & & & 1 & $-0,005$ & 2,325 \\
\hline
\end{tabular}

This table reports pearson correlations between each of the variables used in subsequent analysis. QBASP: is the averaged quoted spreads, SCOR: The total points from the index published for each company, STRAT: index of the strategic information, NFINAN: index of the non-financial information, FINAN: index of the financial information,

VOLM: is the logarithm of the averaged volume exchanged. VOLAT: is by the annual average of stock return standard deviation. PRICE: is the annual average of daily closing price. SIZE: is the size of the company measured by the natural logarithm of year end market capitalization. USCOT: dummy variable 1 if the company listing in the U.S Market and 0 if not. IFRS: dummy variable, 1 for observations from years 2005-2007 and 0 for 2004. VIF: is the inflation factor. ${ }^{* *}, *$ : T-statistics are significant at the $1 \%$ and $5 \%$ levels.

\subsection{Multivariate Analysis}

Table 5 presents the results of the bid-ask spread regression. The results show that there is a negative and statistically significant relationship at the $5 \%$ level between the extent of corporate disclosure and the bid-ask spread. This result means that the extent of information disclosure improves the stock market liquidity. Corporate disclosure is viewed as a positive signal to restore confidence in the market and attract investors to trade in a transparent environment. Empirical studies by Leuz and Verrecchia (2000), Heflin et al. (2005) and Espinosa et al. (2008) confirm the positive relationship between the extent of disclosure and market liquidity in the U.S., Spain and German, respectively.

We also run regressions using the sub-indexes of the corporate disclosure index to identify the impact of strategic, financial and non-financial information separately on market liquidity. Results in Table 5 show a negative 
and significant relationship between financial and non financial indexes and bid-ask spread. This is not the case for the index of strategic information which reveals a positive and insignificant coefficient. Thus, financial and nonfinancial information help investors in their investments' choices. Strategic information may be attractive for longterm positions, but does not increase liquidity.

Table 5 also shows that the relationship between trading volume and bid-ask spread is negative and significant suggesting that the increase in trading volume is associated with an increased capacity of operators to carry out transactions without any impact on prices. This, in turn, will allow a decrease in the risk related to the upholding of stocks and there by a shrink in bid-ask spreads. This result is consistent with the one found by Chae (2005) and Heflin et al. (2005).

Volatility of prices influences positively and significantly quoted spreads. As stock returns are volatile, the probability of negotiating with informed investor increases. Investors are subsequently inclined to increase their bid prices and to decrease their ask prices, widening the bid-ask spread. This finding is consistent with that of Amihud and Mendelson (1980) and Espinosa et al. (2008) and suggest that shares with weak price have large spreads. This relationship is largely determined by the cost of processing orders. These costs decrease by price value because they are spread over a greater number of units of currency for the securities at high prices (Stoll 1978). The coefficient of share price variable is negative and significant. This outcome indicates that shares with weak price have large spreads which confirms the one find by Lafond, Lang and Skaife (2007).

U.S. listing is negatively associated with the spread. Indeed, listed companies in the U.S. market disclose annual reports according to the US GAAP and are then more informative. Finally, companies are experiencing a decrease in the information asymmetry and improve in liquidity during the period of compliance with IFRS as found by Maghraoui and Dumontier (2006) on a sample of German companies. The adoption of these standards results in improving the quality and quantity of accounting and financial information disclosed by French companies.

Table 5. Regression Of Quoted Spreads

\begin{tabular}{lcccc}
\hline \multicolumn{1}{c}{ LnQBASP } & \multicolumn{3}{c}{ LnQBASP } & t \\
\hline Constante & Coef. & T & Coef. & $(-10.33)$ \\
SCOR & $-3.630^{* * *}$ & $(-9.28)$ & $-3.578^{* * *}$ & $(-0.11)$ \\
STRAT & $-0.296^{* * *}$ & $(-2.26)$ & -0.012 & $(-1.87)$ \\
NFINAN & & & $-0.183^{*}$ & $(-2.10)$ \\
FINAN & & & $-0.240^{* *}$ & $(-9.98)$ \\
LnVOLM & & $-0.208^{* * *}$ & 3.53 \\
LnVOLAT & $-0.208^{* * *}$ & $(-9.98)$ & $0.176^{* * *}$ & $(-2.95)$ \\
LnPRICE & $0.176^{* * *}$ & 3.53 & $-0.076^{* * *}$ & $(-10.8)$ \\
SIZE & $-0.076^{* * *}$ & $(-2.95)$ & -0.189 & $(-6.91)$ \\
USCOT & -0.189 & $(-10.8)$ & $-0.360^{* * *}$ & $(-6.33)$ \\
IFRS & $-0.360^{* * *}$ & $(-6.91)$ & $-0.294^{* * *}$ & 0.732 \\
\hline R & $-0.294^{* * *}$ & $(-6.33)$ & $43.89(0.000)$ & \\
\hline F-statistic & 0.736 & & & \\
\hline
\end{tabular}

This table presents the results of linear regressions of quoted bid-ask spread. LnQBASP: is the logarithm of the averaged quoted spreads, VOLM: is the logarithm of the averaged volume exchanged. SCOR: The total points from the index published for each company, STRAT: index of the strategic information, NFINAN: index of the non-financial information, FINAN: index of the financial information. VOLAT: is by the annual average of stock return standard deviation. PRICE: is the annual average of daily closing price. SIZE: is the size of the company measured by the natural logarithm of year end market capitalization. USCOT: dummy variable 1 if the company listing in the U.S Market and 0 if not. IFRS: dummy variable, 1 for observations from years 2005-2007 and 0 for $2004 . \mathrm{R}^{2}$ is the explanatory power of the model. ***, **, ${ }^{*} \mathrm{~T}$-statistics are significant at the $1 \%, 5 \%$ and $10 \%$ levels respectively.

As far as the component of adverse selection is concerned, table 6 shows a negative and significant relationship between the extent of disclosure and the adverse selection component of the spread. Signaling through 
the mechanisms of information is an essential tool that helps reducing adverse selection and then the gap between anticipation investors. Fewer information asymmetry results in a reduction of the adverse selection problem, which implies a reduced spread. Investors tend to invest in the securities transparent protecting against research costs of private information. Sreedhar, Paolo and Guojun (2009) argue that in an information asymmetry environment, uninformed investors (small investors) are likely to refuse to trade. This result is in line with Charoenwonget al. (2011) findings on the Singapore market suggesting that investors are more interested in a rich-informational environment as they benefit from reducing the information asymmetry component.

Table 6. Regression Of Bid-Ask Spread Adverse Selection Component

\begin{tabular}{|c|c|c|c|c|}
\hline & \multirow{2}{*}{$\begin{array}{c}\text { LnADSE } \\
\text { Coef. }\end{array}$} & \multicolumn{3}{|c|}{ LnADSE } \\
\hline & & $\mathrm{t}$ & Coef. & $\mathrm{t}$ \\
\hline Constante & $-5,354 * * *$ & $(-12,26)$ & $-5,281 * * *$ & $(-12,61)$ \\
\hline SCOR & $-0,301 * *$ & $(-2,13)$ & & \\
\hline STRAT & & & $-0,036$ & $(-0,30)$ \\
\hline NFINAN & & & $-0,214^{*}$ & $(-1,73)$ \\
\hline FINAN & & & $-0,252 * *$ & $(-2,04)$ \\
\hline LnVOLM & $-0,206 * * *$ & $(-13,78)$ & $-0,204 * * *$ & $(-13,82)$ \\
\hline LnVOLAT & $0,168 * * *$ & 3,04 & $0,166^{* * *}$ & 3,09 \\
\hline LnPRICE & $-0,074 * * *$ & $(-2,62)$ & $-0,071 * * *$ & $(-2,47)$ \\
\hline SIZE & $-0,183 * * *$ & $(-9,77)$ & $-0,181 * * *$ & $(-9,51)$ \\
\hline USCOT & $-0,395 * * *$ & $(-7,19)$ & $-0,380 * * *$ & $(-6,76)$ \\
\hline IFRS & $-0,241 * * *$ & $(-4,81)$ & $-0,245 * * *$ & $(-4,86)$ \\
\hline $\mathbf{R}^{2}$ & 0,703 & & 0,699 & \\
\hline F-statistic & $42,61(0,0$ & & $42,74(0,0$ & \\
\hline
\end{tabular}

This table presents the results of linear regressions of adverse selection component of the spread. ADSE: adverse selection component of the spread, SCOR: The total points from the index published for each company, STRAT: index of the strategic information, NFINAN: index of the non-financial information, FINAN: index of the financial information. VOLM: is the logarithm of the averaged volume exchanged., VOLAT: is by the annual average of stock return standard deviation. PRICE: is the annual average of daily closing price. SIZE: is the size of the company measured by the natural logarithm of year end market capitalization. USCOT: dummy variable 1 if the company listing in the U.S Market and 0 if not. IFRS: dummy variable, 1 for observations from years 2005-2007 and 0 for $2004 . \mathrm{R}^{2}$ is the explanatory power of the model. ***,**,* T-statistics are significant at the $1 \%, 5 \%$ and $10 \%$ levels respectively.

\subsection{Robustness Checks}

We check the robustness of our findings by using effective spread, trading volumes and Illiquidity ratio Amihud (2002) as alternative measures for liquidity.

Effective spread: is the difference between the price of a newly issued stock and its actual price with an adjustment for the effect of the offering's announcement. Locke and Venkatesh (1997) and Ferguson and Mann (2001) show that quoted spread estimators are unrelated to the aggregate customer execution costs in future markets. The effective spread better captures the cost of a round-trip order by including price movement. This second measure indicates the narrowness and the immediacy of the market by indicating the volume on the purchase that can be instantly absorbed by the supply.

Fourchette effective $^{4}=2 \frac{\left|\frac{A s k_{t}+B i d_{t}}{2}-P_{t}\right|}{\frac{A s k_{t}+B i d_{t}}{2}}$

\footnotetext{
${ }^{4}$ Roll (1984) a estimé la fourchette effective au lieu de la mesurer directement. Ses travaux reposent essentiellement sur la mise en évidence du lien existant entre les autocovariances des rentabilités et la taille de la fourchette.
} 
Trading volume: liquidity can also be measured by the average trading volume. It shows the width of market, reflects the popularity of assets on it and signals any new information. Leuz and Verrecchia (2000) and Chae (2005) studied the informational value of trading volume. Unlike the bid-ask spread, this measure is an increasing liquidity function. Therefore, the higher the trading volume, the more liquid is the market (Hamon and Jacquillat, 1992).

Asset non-liquidity: is based on the relationship between the performance and the volume as defined by Amihud (2002). It takes into account two dimensions of the market liquidity: depth, i.e. the volume of units that can be traded without significantly impacting prices, and resilience, i.e. the speed with which fluctuations due to transactions disappear. For an asset class, the mean illiquidity ratio is defined by (multiplied by $10^{6}$ ):

Illiquidity ratio $=\frac{1}{D_{j}} \sum \frac{\left|R_{j}\right|}{\left(\operatorname{Vol}_{j} * P_{j}\right)}$

With $\mathrm{D}_{\mathrm{j}}$ to represent the number of days an asset has been quoted, $\left|R_{j}\right|$ the absolute vale of daily return, $\mathrm{Vol}_{\mathrm{j}}$ the volume of daily transactions, and $\mathrm{Pj}$ the asset quotation on $\mathrm{d}$ day. Hasbrouck (2002) assumes that this measure is the best one to capture Kyle's lamba. This measurement is based on the days without price changes, which is an advantage. This ratio is positively associated with the bid-ask spread; a small bid-ask spread is linked with a limited impact on prices (Lesmond 2005).

Table 7 shows a positive and significant relationship between trading volume and the extent of corporate disclosures. This result is coherent with previous models showing that the extent of disclosure improves liquidity. Overall, the results remain unchangeable to the use of alternative measures of liquidity.

Table 7. Regression Of Effective Spread, Trading Volumes And Illiquidity Ratio

\begin{tabular}{|c|c|c|c|c|c|c|}
\hline & LnEBASP & & LnVOLM & & ILLIQ & \\
\hline & Coef. & $\mathrm{T}$ & Coef. & $\mathrm{t}$ & Coef. & $\mathrm{t}$ \\
\hline Constant & $-3.643 * * *$ & $(-9.78)$ & $-3.578 * * *$ & $(-10.33)$ & $-9.09 * * *$ & $(-16.86)$ \\
\hline SCOR & $-0.407 * * *$ & $(-3.03)$ & $1.462 * * *$ & 3.75 & -0.077 & $(-0.186)$ \\
\hline LnVOLM & $-0.197 * * *$ & $(-13.37)$ & & & $-0.507 * * *$ & $(-13.29)$ \\
\hline LnVOLAT & $0.198 * * *$ & 3.89 & $0.557 * * *$ & 3.75 & 0.22 & 1.4 \\
\hline LnPRICE & $-0.037^{*}$ & $(-1.88)$ & $-0.832 * * *$ & $(-11.33)$ & -0.12 & $(-0.95)$ \\
\hline SIZE & $-0.197 * * *$ & $(-11.10)$ & $0.787 * * *$ & 17.9 & $-0.835 * * *$ & $(-14.16)$ \\
\hline USCOT & $-0.404 * * *$ & $(-7.75)$ & $1.440 * * *$ & 10.01 & $-0.081 * * *$ & $(-6.9)$ \\
\hline IFRS & $-0.318 * * *$ & $(-6.68)$ & 0.134 & 0.967 & $-0.445 * * *$ & $(-3.06)$ \\
\hline $\mathbf{R}^{2}$ & 0.716 & & 0.537 & & 0.672 & \\
\hline F-statistic & $57.41(0.000)$ & & $95.35(0.000)$ & & $89.19(0.000)$ & \\
\hline
\end{tabular}

This table presents the results of linear regressions of effective bid-ask spread, trading volume and illiquidity ratio. EBASP: is the logarithm of the averaged effective spread. LnVOLM: is the logarithm of the averaged volume exchanged. ILLIQ: is illiquidity ratio. SCOR: The total points from the index published for each company, VOLM: is the logarithm of the averaged volume exchanged., VOLAT: is by the annual average of stock return standard deviation. PRICE: is the annual average of daily closing price. SIZE: is the size of the company measured by the natural logarithm of year end market capitalization. USCOT: dummy variable 1 if the company listing in the U.S Market and 0 if not. IFRS: dummy variable, 1 for observations from years 2005-2007 and 0 for 2004. $\mathrm{R}^{2}$ is the explanatory power of the model. ***,**, ${ }^{*}$ T-statistics are significant at the $1 \%, 5 \%$ and $10 \%$ levels respectively.

\section{CONCLUSION}

The purpose of this paper is to shed the light on the relationship between corporate disclosures, information asymmetry and stock market liquidity in France.

The results show a positive relationship between the extent of corporate disclosure and market liquidity suggesting that a rich-informational environment is likely to improve stock market liquidity resulting from increased 
trading volumes. The findings also show a positive effect of corporate disclosure on information asymmetry through a decrease in the adverse selection component of the spread. This finding suggests that information device is crucial to help reducing adverse selection and then the gap between investors. The decomposition of the total score into subindices shows that non-financial and financial information are important in trading decisions. Strategic information may be attractive for long-term positions.

This research provides some contributions to previous literature, particularly on the effect of information disclosure on stock-market liquidity and information asymmetry. This should encourage managers to consider disclosure as a means to prevent the illiquidity risk and to better assess security market' values. In this context, the adoption of IFRS, which contributes to improve stock-market liquidity, is a response to this objective. These standards help French firms to improve their informational environment and enhance market liquidity.

\section{AUTHOR INFORMATION}

Aymen Ajina, Ph.D. (Management Sciences-Finance), HEC Management School-University of Liège, ISGUniversity of Sousse and member of the Research Laboratory LAMIDED. His major publications include the Markets and Investors, International Management, The International Journal of Managerial Finance among others. His research interests are on corporate governance, financial disclosure and market liquidity. E-mail: ayman.ajina@gmail.com

Danielle Sougne, Ph.D. and Professor in Finance at the University of Liège (Belgium), PWC-KBL Chairholder in Fund Industry. Her major publications include Journal of Empirical Finance, Journal of Asset Management, Applied Financial Economics, Managerial Finance, International Journal of Managerial Finance among others. Her research includes three main areas of investigation the fund investment decision-making process, fund risk and performance management and fund corporate governance. E-mail: danielle.sougne@ulg.ac.be

Faten Lakhal, PhD. and a Professor in Accounting at the University of Sousse (Tunisia) and a fellow researcher at the Institut de Recherche en Gestion at Paris-Est University (France). Her major publications include the Review of Accounting and Finance, Bankers, Markets and Investors, Managerial Finance, The International Journal of Business, Managerial Auditing Journal, The International Journal of Managerial Finance among others. Her special research interests are in corporate governance, corporate disclosure, earnings quality and gender diversity. E-mail: lakhal@u-pec.fr

\section{REFERENCES}

Acharya, V., \& Pedersen, H. (2005). Asset pricing with liquidity risk. Journal of Financial Economics, (77), 375410.

Acker, D., Stalker, M., \& Tonks, I. (2002). Bid-ask spreads around earnings announcements. Journal of Business, Finance and Accounting, (29), 1149-1179

Amihud, Y. (2002). Illiquidity and stock returns: Cross-section and time-series effects. Journal of Financial Markets, (5), 31-56.

Amihud, Y., \& Mendelson, H. (1980). Dealership market: market making with inventory. Journal of Financial Economics, (8), 311-353.

Ascioglu, A., Hegde, P., McDermott J., \& Krishnan, G. (2007). Earnings quality and market liquidity. Workin paper, George Mason University.

Bagehot, W. (1971). The only game m town. Financial Analysts Journal, (27), 12-14.

Bailey, W., Li, H., Mao, C., \& Zhong, R, (2003). Regulation Fair Disclosure and Earnings Information: Market, Analyst, and Corporate Responses. Journal of Finance, (58), 2487-2514.

Bartov, E., \& Bodnar, M. (1996). Alternative Accounting Methods, Information Asymmetry and Li-quidity: Theory and Evidence. The Accounting Review, (71), 397-418.

Biais, B., Foucault, T., \& Hillion, P. (1997). Microstructure des marchés financiers. Institutions, modèles et tests empiriques. PUF, Paris.

Biais, B., Glosten, L., \& Spatt, C. (2005). The Microstructure of Stock Markets. CEPR, Discussion paper .

Botosan, C. (1997). Disclosure level and the cost of equity capital. The Accounting Review, (72), 323-349. 
Botosan, C., \& Frost, C. (2000). Regulation, Disclosure and Market Liquidity. Working paper, Washington University and Dartmouth College.

Brockman, P., \& Chung, Y. (1999). Bid-ask spread components in an order-driven environment. Journal of Financial Research, (22), 227-246.

Brockman, P., \& Chung, Y. (2001). Managerial Timing and Corporate Liquidity: Evidence from Actual Share Repurchases. Journal of Financial Economics, (61), 417-448.

Brown, S., \& Hillegeist, A. (2007). How disclosure quality affects the level of information asymmetry. Review of Accounting Studies, (12), 443-477.

Chae, J. (2005), « Timing information, information asymmetry, and trading volume », The Journal of Finance, (61), 413-442.

Charoenwong, C., Ding, D., \& Visaltanachoti, N. (2011). Adverse selection and corporate governance. International Review of Economics and Finance. (20), 406-420.

Cohen, D. (2006). Does information risk really matter? An analysis of the determinants and economic consequences of financial reporting quality. Working paper, North-western University.

Cohen, K., Maier, S., Schwartz, R., \& Whitcomb, D. (1981). Transaction costs, order placement strategy, and existence of the bid-ask spread. Journal of Political Economy, (89), 287-305.

Copeland, T., \& Galai, D. (1983). Information effects of the bid-ask spread. Journal of Finance, (38), 1457-1469.

Winne, R., \& Majois, C. (2004). A comparison of alternative spread decomposition models on Euronext Brussels. Les cahiers économiques de Bruxelles, (46).

Demsetz, H. (1968). The Cost of Transacting. Quarterly Journal of Economics, (82), 33-53.

Dennis, P., \& Weston, J. (2001). Who's Informed? An Analysis of Stock Ownership and Informed Trading. working paper.

Diamond, D., \& Verrecchia, R. (1991). Disclosure, liquidity, and the cost of capital. Journal of Finance, (46), 13251359.

Ding, Y., \& Stolowy, H. (2003). Les facteurs déterminants de la stratégie des groupes français en matière de communication sur les activités de R\&D. Finance Contrôle Stratégie, (6), 39-62.

Dumontier, P., \& Maghraoui, R. (2006). Adoption volontaire des IFRS, asymétrie d'information et fourchettes de prix : l'impact du contexte informationnel. Comptabilité-Contrôle-Audit, (12), 1-21.

Easley, D., \& O'Hara, M. (1987). Price, Trade Size, and Information in Securities Markets. Journal of Financial Economics, (19), 69-90.

Edwards, A., Harris, L., \& Piwowar, M. (2007). Corporate bond market transaction costs and transparency. The Journal of Finance, (62).

Eng, L., \& Mak, Y. (2003). Corporate governance and voluntary disclosure. Journal of Accounting and Public Policy, (22), 325-345.

Espinosa, M., Tapia, M., \& Trombetta, M. (2008). Disclosure and Liquidity in a Driven by Orders Market: Empirical Evidence from Panel Data. Investigaciones Económicas, (32). 339-370.

Fama, E., \& French, K. (1992). The Cross-Section of Expected Stock Returns. Journal of Finance, (47), 427-466.

Francis, J., Dhananjay, N., \& Xin, W. (2006), « Re-Examining the Effects of Regulation Fair Disclosure Using Foreign Listed Firms to Control for Concurrent Shocks. Journal of Accounting and Economics, (41), 271292.

Gassen, J., \& Sellhorn, T. (2006). Applying IFRS in Germany-Determinants and Consequences. working paper, www.ssrn.com.

George, T., Kaul, G., \& Nimalendran, M. (1991). Estimation of the Bid-Ask Spread and its Components: A New Approach », Review of Financial Studies, (4), 623-656.

Glosten, L., \& Harris, E. (1988). Estimating the Components of the Bid-Ask Spreads », Journal of Financial Economics, (21), 123-142.

Glosten, L., \& Milgrom, P. (1985). Bid, Ask and Transaction Prices in a Specialist Market with Heterogeneously Informed Traders. Journal of Financial Economics, (14), 71-100.

Grossman, S., \& Miller, H. (1986). Liquidity and Market Structure. the Journal of Finance, (43), 617-633.

Gruning, M. (2010), « Capital Market Implications of Corporate Disclosure: German Evidence. Official Open Access Journal of $V H B$.

Gujarati, N. (2004). Économétrie. Traduction de la 4ème édition américaine par Bernard Bernier. Edition de Boeck. Hamon, J., \& Jacquillat, B. (1992). Le marché français des actions. Études empiriques 1977-1991. Collection finance, $P U F$. 
Handa, P., Schwartz, R., \& Tiwari, A. (1998). The ecology of an order-driven market. Journal of Portfolio Management, (24), 47-55.

Hasbrouck, J. (2006). Trading costs and returns for US equities: stimating effective Costs from Daily Data. Working Paper, Stern School of Business, New York University.

Healy, P., \& Palepu, K. (2001). Information asymmetry, corporate disclosure, and the capital markets: a review of the empirical disclosure literature. Journal of Accounting and Economics, (31), 405-440.

Healy, P., Hutton, A., \& Palepu, K. (1999). Stock Performance and Intermediation Changes Surrounding Sustained Increases in Disclosure. Contemporary Accounting Research, (16), 485-520.

Heflin, F., \& Shaw, W. (2000). Blockholder Ownership and Market Liquidity. Journal of Financial and Quantitative Analysis, (35), p. 621-633.

Heflin, F., Shaw, W., \& Wild, J. (2005). Disclosure policy and market liquidity: Impact of depth quotes and order sizes. Contemporary Accounting Research, (22), 829-866

Holsmtröm, B., \& Tirole, J. (2001). LAPM : a liquidity based asset pricing model. Journal of Finance, (56), 18371867.

Huang, R., \& Stoll, H. (1994). Market microstructure and stock return predictions. Review of financial studies, (7), 179-213.

Huang, R., \& Stoll, H. (1997). The components of the bid-ask spread: A general approach. Review of Financial Studies, (10), 995-1034.

Kyle, A. (1985). Continuous Auctions and Insider Trading. Econometrica, (53), 1315-1335.

Lafond, R., Lang, M., \& Skaife, H. (2007). Earnings smoothing, governance and liquidity: International evidence. Working paper, University of North Carolina.

Lakhal, F. (2008). Les mécanismes de gouvernement des entreprises et les publications volontaires des résultats en France. Comptabilité, Contrôle, Audit, (2), 69-92.

Lakhal, F. (2008). Stock market liquidity and information asymmetry around voluntary earnings disclosures: New evidence from France. International Journal of Managerial Finance, (4), 60-75.

Lang, M., \& Lundholm, R. (1993). Cross-Sectional Determinants of Analyst Ratings of Corporate Disclosures. Journal of Accounting Research, (31), 246-271.

Leuz, C., \& Verrecchia, R. (2000). The economic consequences of increased disclosure. Journal of Accounting Research, (38), 91-124.

Lin, C., Sanger, G., \& Booth, G. (1995). Trade size and the components of the bid ask spread. Review of financial studies, (8), 1153-1183.

Mannaï, S. (1995). De la microstructure en général et de la liquidité en particulier. Economica, Paris.

Myers, S., \& Majluf, N. (1984). Corporate financing and investment decisions when firms have information that investors do not have. Journal of Financial Economics, (13), 187-221.

Neter, J., Wasserman, W., Kunter, M. (1989). Applied Linear Regression Models. 2nd edition, Irwin, Homewood.

O'Hara, M. (1995). Market Microstructure Theory. Basil Blackwell, New York.

Petersen, C., \& Plenborg, T. (2006). Voluntary disclosure and information asymmetry in Denmark. Journal of International Accounting, Auditing and Taxation, (15), 127- 149.

Prat dit Hauret, C. (2004). La révélation des faits délictueux par les commissaires aux comptes : une décision contextuelle. Revue Sciences de Gestion.

Roll, R. (1984). A Simple Implicit Measure of the Effective Bid-Ask Spread in an Efficient Market. Journal of Finance, (39), 1127-1139.

Rubin, A. (2007). Ownership level, Ownership concentration and liquidity. Journal of Financial Markets, (10), 219248.

Sarin, A., Shastri, A., \& Shastri, K. (2000). Ownership structure and stock market liquidity. Working Paper, Santa Clara University.

Sharma, L. (2005). Ownership Structure and Stock Liquidity, Evidence from Indian Market. Working paper.

Sreedhar, B., Paolo, P., \& Guojun, W. (2009). Does asymmetric information drive capital structure decisions?. Review of Financial Studies, (22), 3211-3243.

Van Ness, B., Van Ness, R., \& Warr, R. (2001). How well do adverse selection components measure adverse selection?. Financial Management, (30), 77-98.

Verrecchia, R. (2001). Essays on disclosure. Journal of Accounting and Economics, (32), 97-180 


\section{NOTES}

